AGRIEKONOMIKA

http://journal.trunojoyo.ac.id/agriekonomika

Volume 10, Nomor 1, 2021

https://doi.org/10.21107/agriekonomika.v10i1.9740
Agriekonomika has been accredited as a scientific journal by the Ministry of

Research-Technology and Higher

Education Republic of Indonesia: No.

23/E/KPT/2019

\title{
Electronic Word of Mouth Pemasaran Madu Era Covid-19 di Wilayah Malang
}

\author{
${ }^{凶 1}$ Puji Akhiroh, ${ }^{2}$ Dewi Masyithoh dan ${ }^{1}$ Agus Susilo \\ ${ }^{1}$ Fakultas Peternakan, Universitas Brawijaya, Indonesia \\ ${ }^{2}$ Fakultas Peternakan, Universitas Islam Malang, Indonesia \\ Received: Januari 2021; Accepted: April 2021; Published: April 2021
}

\begin{abstract}
ABSTRAK
Madu menjadi produk primadona pada saat pandemik Covid 19. Madu merupakan produk alami yang terbukti memiliki dampak yang baik bagi kesehatan dan dapat menjaga imunitas tubuh. Ulasan pada google dapat kita sebut sebagai electronic word of mounth (eWOM). eWOM yang saat ini kita kenal dahulu kita sebut sebagai WOM merupakan pendapat dari seseorang terhadap suatu produk yang digunakan sebagai cara untuk menilai suatu produk. Produk yang memiliki penilaian serta ulasan yang baik secara tidak langsung akan meningkatkan pemasaran produk tersebut serta reputasi dari penjual produk karena masyarakat cenderung mempercayai rekomendasi oleh orang yang dipercaya seperti artis, tetangga, kerabat terdekat dan komentar yang disertakan bukti gambar atau video pada ulasan google. Wilayah Malang Jawa Timur memiliki penjual maupun produsen madu. Beberapa penjual madu di Wilayah Malang telah memasuki penjualan secara online dengan menampilkan usaha pada Google. Penelitian ini bertujuan untuk menganalisis mengenai eWOM produk madu di wilayah Malang serta mendeskripsikan mengenai rating dan ulasan yang terdapat pada mesin pencari Google terhadap produsen dan penjual madu di wilayah Malang.
\end{abstract}

Kata kunci: Pemasaran, Madu, eWOM, Ulasan, Google.

Electronic Word of Mouth Marketing of Honey in the Covid-19 Era in Malang Region

\begin{abstract}
Honey is a prima donna product during the Covid 19 pandemic. Honey is a natural product that is proven to have a good impact on health and can maintain body immunity. Reviews on Google can be referred to as electronic word of mount (eWOM). eWOM, which we know today as WOM, is someone's opinion of a product that is used as a way to evaluate a product. Products that have good ratings and reviews will indirectly increase the marketing of these products and the reputation of product sellers because people tend to trust recommendations by trusted people such as artists, neighbors, closest relatives and comments that include image or video evidence on Google reviews. The Malang area of East Java has both sellers and producers of honey. Several honey sellers in the Malang Region have entered online sales by displaying their business on Google. This study aims to analyze the eWOM of honey products in the Malang area and describe the ratings and reviews found on the Google search engine for honey producers and sellers in the Malang region.
\end{abstract}

Keyword: Marketing, Honey, eWOM, Reviews, Google.

\footnotetext{
Corresponding author:

Email : pujiakhiroh@ub.ac.id
} 


\section{PENDAHULUAN}

Pandemi Covid-19 yang sedang berlangsung membuat kita harus mampu berdampingan dengan virus tersebut. Salah satu cara untuk bertahan melawan Covid-19 adalah dengan menjaga daya tahan tubuh. Daya tahan tubuh dapat tercapai dengan mengkonsumsi produk yang terbukti memiliki efek yang baik bagi kesehatan tubuh. Banyak produk yang direkomendasikan untuk memperkuat daya tahan tubuh, salah satu dari produk tersebut adalah madu. Menurut Tim Kerja Kementerian Dalam Negeri (2020), senyawa anti-infamasi pada jahe dicampur dengan madu, memiliki efek antioksidan yaitu zat yang dapat melindungi tubuh dari radikal bebas. Lebih lanjut dijelaskan (Nanda dkk., 2017), madu telah dipelajari terhadap berbagai penyakit pada manusia dan menunjukkan spectrum yang luas pada sifat terapeutik seperti efek anti-inflammatory, anti bakteri, antimutagenic, antiviral, antidiabetic, antifungal, antitumoural dan mempercepat penyembuhan luka. Salah satu khasiat madu dalam anti-bacterial ada pada penyembuhan Pharyngitis atau radang tenggorokan. Menurut (Kamilah, 2019) dalam sebuah tinjauan, madu yang merupakan cairan manis dapat mengobati batuk dan memiliki banyak efek yang diamati. Hipotesis menunjukkan zat-zat manis secara alami menyebabkan air liur refleks dan produksi lendir saluran napas yang mengarah ke efek demulen pada faring dan laring, sehingga dapat mengurangi batuk.

Madu sudah dikenal sejak dahulu kala sebagai hasil dari lebah yang dapat dimanfaatkan manusia untuk digunakan untuk memperkuat daya tahan tubuh dan menambah kesehatan. Pada era pandemic madu banyak diburu masyarakat untuk dapat membantu menangkal Covid-19 dengan cara memperkuat imunitas tubuh. Menurut (Eteraf-Oskouei \& Najafi, 2013) madu memiliki efek anti-inflammaory yang bebas dari efek samping. Sehingga madu banyak dikonsumsi masyarakat terutama anak-anak untuk mengurangi berbagai macam penyakit, termasuk batuk dan radang tenggorokan.

Kondisi pandemi Covid-19 membuat aktivitas berkegiatan dibatasi dan sebagian besar waktu kita habiskan dengan bekerja dari rumah. Meskipun bekerja dari rumah kebutuhan terkait kesehatan tubuh harus tetap terpenuhi, untuk itu banyak orang mempercayakan kebutuhan mereka dengan memakai delivery service dan melakukan proses berbelanja dari gadget mereka. Lebih lanjut (Mungkasa, 2020) Pandemi Covid 2019 mencetuskan pemerintah untuk membuat kebijakan bekerja dari rumah sehingga kebijakan tersebut diadopi oleh perusahaan yang menerapkan kebijakan serupa untuk mencegah penyebaran virus. Berbelanja menggunakan gadget tentu saja berkaitan erat dengan berbelanja menggunakan internet. Masyarakat dalam berbelanja terlebih dahulu akan melakukan proses pencarian pada mesin pencari. Menurut (Harahap, 2018) terdapat faktor-faktor yang mempengaruhi masyarakat dalam melakuakan belanja secara online perasaan percaya yang timbul, penerapan harga, perasaan nyaman ketika berbelanja, menawarkan hal yang mudah untuk dilakukan dan stock barang yang tersedia, selain itu faktor tambahan yang mempengaruhi adalah perasaan aman saat berbelanja produk yang dipastikan berkualitas, tampilan dari laman website yang menarik serta keinginan berbelanja yang kuat dari masyarakat. Salah satu mesin pencari yang kita kenal adalah google. Mesin pencari akan secara real time menampilkan penjual dan produsen madu disekitar kita. Wilayah Malang merupakan salah satu penghasil madu di Jawa Timur, beberapa bahkan memproduksi madu sendiri serta terdapat beberapa penjual yang menjual madu di wilayah Malang yang telah menggunakan internet sebagai tempat untuk memasarkan produk lebih dekat dengan konsumen. (Jayuli et al., 2018) Kabupaten Malang merupakan wilayah yang memiliki ketinggian tempat yang beragam mulai dari 0-3000 meter di atas permukaan laut (dpl). 
Setiap ketinggian di daerah Kabupaten Malang memiliki vegetasi tumbuhan yang beragam di setiap ketinggiannya. Terdapat banyak jenis tumbuhan yang dapat digunakan sebagai pakan bahan lebah untuk memproduksi madu dan polen dapat dipengaruhi oleh ketinggian suatu wilayah. Semakin tinggi suatu wilayah potensi vegetasi akan semakin baik. Data polen di Desa Borogondang, Kecamatan Karangploso, kemudian di Desa Druju, Kecamatan Sumbermanjing Wetan, dan Pantai Ngliyep, Desa Kedung Salam, Kecamatan Donomulyo yang merupakan sumber polen bagi $A$. cerana atau tidak, dapat digunakan sebagai database polen di Kabupaten Malang, dan tumbuhan yang mempunyai periode pembungaan pada bulan Februari.

Google merupakan salah satu platform yang dapat digunakan masyarakat untuk mencari informasi misalnya ketika masyarakat membutuhkan rekomendasi toko penjualan madu. Sepanjang meningkatnya teknologi terdapat fitur google seperti ulasan yang akan menambakan nilai jual terhadap produk yang direkomendasikan sehingga dapat memaksimalkan pemasaran. Saat ini google menjadi sarana untuk dapat melakukan promosi produk agar dapat menjangkau target pasar secara luas. Namun, penggunaan google untuk promosi juga harus diperhatikan strateginya seperti branding produk yang digunakan dan penggunaan Celebrity endorser. Celebrity endorser merupakan pendukung dari suatu produk untuk dapat menyampaikan pesan kuat terhadap citra sebuah produk melalui media yang digunakan (Purbohastuti \& Hidayah, 2020). Hal itu dilakukan karena masyarakat cenderung mempercayai rekomendasi oleh orang yang dipercaya seperti artis, tetangga dan kerabat terdekat maka strategi eWOM dapat diterapkan dalam menjangkau target pasar. Penelitian terkait eWOM banyak dilakukan pada produk saja dan minim dilakukan pada produk peternakan dalam hal ini belum ada penelitian terkait eWOM pada produk madu. Penelitian terkait
eWOM penting dilakukan karena, era digital semakin tumbuh subuh dan menjadi pilihan berbelanja bagi masyarakat. Perkembangan ilmu pengetahuan pemasaran hasil ternak perlu mendapat perhatian dari peneliti untuk dapat melakukan evaluasi kemajuan pemasaran terutama pada bidang peternakan. Pengenalan cara baru, serta potensi baru pada usaha dibidang peternakan akan memperkuat kepercayaan baik bagi pelaku usaha maupun konsumen bahwa produk yang beredar memiliki branding yang kuat selain secara online maupun offline.

Pengamatan terhadap penjual madu akan lebih detail dilakukan oleh masyarakat sehingga kebutuhan masyarakat terhadap madu terpenuhi sesuai dengan jenis madu, khasiat dan beberapa pertimbangan lain misal jarak dari rumah ke lokasi penjual serta rating tinggi dan ulasan positif dari pembeli lain. Menurut López \& Sicilia (2014), WOM didefinisikan sebagai "percakapan tatap muka antara konsumen tentang suatu produk atau pengalaman layanan. Ulasan yang terdapat pada mesin pencari Google dapat kita sebut sebagai electronic Word of Mouth (eWOM). eWOM pada ulasan tersebut memiliki fungsi yaitu memberikan gambaran serta pengalaman menggunakan suatu produk sehingga pembeli yang berniat akan membeli suatu saat akan dapat menilai produk secara positif maupun negatif, sehingga mereka akan mempunyai alasan kuat untuk membeli atau tidak terhadap suatu produk yang sudah mendapat eWOM dari orang yang sudah pernah mempunyai pengalaman membeli produk tersebut. Melalui eWOM informasi dapat tersebar secara masiv dalam waktu yang relatif singkat, serta informasi pada eWOM dapat dilihat oleh masyarakat setiap waktu. Sehingga hal ini dapat memiliki andil pada tahap konsumn ingin memutuskan untuk memiliki suatu produk (Jeong and Jang, 2011).

Secara umum Google memberikan eWOM terhadap suatu produk adalah dengan melihat melalui rating dan ulasan. Rating pada google terlihat sebagai bintang, 
bintang 1 artinya buruk, bintang 5 berarti sangat baik. Sedangkan ulasan berisi pengalaman membeli atau pengalaman mendapat pelayanan dari penjual suatu produk. Ulasan merupakan hal terbaik yang bisa diakses oleh masyarakat dan jejak ulasan akan tersimpan dan dapat dijadikan sebagai branding serta membantu pemasaran. Review secara online dapat berkembang apada era informasi digital, sehingga hal tersebut adalah sama dengan hal yang dulu kita kenal sebagai word of mouth. Informasi yang tersedia berasal dari masyarakat sehingga hal ini murni terbentuk sebagai sarana komunikasi anta customer suatu produk yang terlepas dari intervensi perusahaan (Diaz \& R, 2018). Menurut Gupta \& Harris (2010), e-WOM digunakan sebagai informasi terkait produk, terutama jika memiliki pengalaman dengan produk dapat digunakan sebagai sarana evaluasi terhadap produk. Lebih lanjut dijelaskan oleh Agustina et al. (2018), penjabaran review secara online dapat kita lihat sebagai pengalaman nyata customer suatu produk setelah membeli produk. Sehingga review yang diberikan adalah jujur terkait pelayanan yang diberikan apakah baik atau tidak, nyaman atau tidak, dan sebaginya. Review ini kemudian dijadikan guideline secara tidak langsung bagi calon pembeli. Review akan menampilkan rating serta dapat mempengaruhi kepercayaan customer dalam memutuskan untuk membeli suatu produk. Menurut Setiawan et al. (2014), mayoritas masyarakat secara aktif terlibat dalam percakapan melalui eWOM, yang paling banyak digunakan media komunikasi eWOM adalah jejaring sosial.

\section{METODE PENELITIAN Sampel}

Sampel dari penelitian ini adalah produsen dan penjual madu di wilayah Malang yaitu PT Kembang Joyo Sriwijaya, Istana Madu Aneka Nektar, Madu Murni, Madu Asoha Malang, Madu Asli Kota Batu, Madu Tawon Asli Malang, Madunesia Madu Malang Asli
Murni. Penelitian ini menggunakan teknik purposive sampling atau dengan sengaja memilih sample yaitu penjual Madu dengan rating dan ulasan lebih dari 10 dan masih berada di Wilayah Malang.

\section{Metode}

Metode yang digunakan pada penelitian ini adalah dengan menggunakan analisis data sebagai kajian dalam bentuk tabel dan mendeskripsikan atau menggambarkan eWOM melaui data yang telah terkumpul pada produk madu di wilayah Malang sehingga pembaca akan mendapat gambaran secara menyeluruh mengenai eWOM produk madu di wilayah Malang.

\section{HASIL DAN PEMBAHASAN \\ Gambaran Wilayah}

Wilayah Malang atau sering disebut Malang Raya terdiri dari Kota Malang, Kota Batu serta Kabupaten Malang. Wilayah sebelah timur dan barat terdapat pegunungan yang mengelilingi (Gunung semeru di bagian timur serta gunung Ajuno dan Panderman di bagian barat). Wilayah bagian selatan dengan ketinggian lebih rendah merupakah wilayah yang berbatasan langsung dengan pantai jawa bagian selatan. Luas wilayah Malang adalah $3,882.44 \mathrm{~km}^{2}$. Jumlah penduduk wilayah Malang menurut sensus 2017 adalah sebanyak 3.642.007 juta jiwa.

Berdasarkan hasil penelitian diperoleh sebanyak 7 produsen serta penjual madu di wilayah Malang yang memiliki ulasan google lebih dari 10 ulasan. Aspek yang akan dideskripsikan dapa penelitian ini adalah rating produsen atau penjual madu serta ulasan baik positif maupun negatif terhadap produsen maupun penjual madu.

Berikut hasil dari rating 7 penjual madu di wilayah Malang yang di akses pada bulan Desember 2020 (Tabel 1).

Berdasarkan hasil penelitian didapat hasil rating google tertinggi diperoleh oleh Madunesia, sedangkan secara ratarata rating yang diraih adalah diatas 4 ini berarti secara kualitas produk dan pelayanan pelanggan menilai bahwa produk dan pelayanan sudah baik, sesuai 
dengan pendapat (Bagaskara, 2017) Rating menunjukkan penilaian masyarakat terhadap produk yang dijual. Rating yang tersaji berupa bintang dari bintang 1 sampai dengan bintang 5 . Semakin banyak bintang pada rating yang dimiliki maka semakin baik kesan yang ingin disampaikan oleh pelanggan. Rating dapat mempermudah pelanggan ketika mencari pada mesin pencarian online. Lebih lanjut dijelaskan oleh (Bagaskara, 2017) bahwa rating tinggi membantu produk dan penjual untuk memasarkan dan secara tidak langsung membranding produk yang mereka jual. Ulasan yang diberikan oleh pelanggan dapat dikatakan lebih penting sebagai guideline dalam membeli dibandingkan dengan rating bintang. Sesuai dengan pendapat Chang \& Wu (2014), e-WOM adalah semacam pertukaran pengetahuan di antara konsumen yang didahului oleh kesempatan, motivasi dan kemampuan. Lebih lanjut dijelaskan bahwa dengan perkembangan yang kuat dari internet, web, dan aplikasi seluler, pelanggan mendapatkan akses informasi yang tidak dibatasi mengenai produk dan perusahaan, menyediakan mereka berbagai macam pilihan dari mana memilih produk dan layanan dengan harga yang sangat kompetitif (Duarte dkk., 2018).

Tingginya rating menjadi salah satu strategi pemasaran agar produk dapat menarik minat konsumen sehingga konsumen akan terus melakukan pembelian ulang dan juga akan mempengaruhi konsumen lain untuk dapat membeli.
Namun untuk memperoleh rating tinggi penjual harus memperhatikan kualitas produk serta pelayanan agar dapat menjangkau target pasar secara luas.

Berikut hasil dari ulasan 7 penjual madu di wilayah Malang yang di akses pada bulan Desember 2020 (Tabel 2).

Jumlah ulasan google pada masingmasing produsen berbeda, PT. Kembang Joyo Sriwijaya memiliki ulasan terbanyak yaitu sebanyak 116 ulasan. Sedangkan produsen maupun penjual lain berkisar antara 15-23 ulasan. Hal ini menunjukkan PT. Kembang Joyo Sriwijaya sudah mendapat pengakuan yang lebih baik dari masyarakat, serta memiliki lebih banyak konsumen yang sudah membeli sehingga ulasan yang diperoleh lebih banyak. PT. Kembang Joyo Sriwijaya dalam menjalani agribisnis sudah dapat berjalan dengan baik dari segi penjualan pada internet dalam hal ini adalah mesin pencari google. Hal ini sesuai dengan pendapat Kumalasari dkk. (2018), bahwa eWOM pada internet dapat memberikan dampak positif pada perkembangan usaha. Empat Dimensi eWOM adalah pertama Concerns for other, kedua Expressing positive feeling, ketiga Helping the company dan terakhir sebagai Economic Incentives. Lebih lanjut dijelaskan oleh Bagaskara (2017), manajemen pemasaran era industri 4.0 perlu memperhatikan reputasi usaha dari segi online melalui ulasan yang banyak di google. Semakin banyak ulasan yang diperoleh maka semakin meyakinkan usaha tersebut dimata konsumen. Menurut

Tabel 1

Rating pada Google

\begin{tabular}{llc}
\hline No. & Nama & Rating \\
\hline 1. & PT. Kembang Joyo Sriwijaya & 4,6 \\
2. & Istana Madu Aneka Nektar & 4,8 \\
3. & Madu Murni & 4,8 \\
4. & Madu Asoha Malang & 4,9 \\
5. & Madu Asli Kota Batu & 4,9 \\
6. & Madu Tawon Asli Malang & 4,8 \\
7. & Madunesia Madu Malang Asli Murni & 5,0 \\
\hline
\end{tabular}

Sumber: Ulasan Google, 2020 
Tabel 2

Jumlah Ulasan dan Contoh Ulasan pada Google

\begin{tabular}{|c|c|c|c|}
\hline No. & Nama & $\begin{array}{l}\text { Jumlah } \\
\text { Ulasan }\end{array}$ & Ulasan \\
\hline 1. & $\begin{array}{l}\text { PT. Kembang } \\
\text { Joyo Sriwijaya }\end{array}$ & 117 & $\begin{array}{l}\text { Madu asli, harga terjangkau, produk berag- } \\
\text { am, pelayanan ramah }\end{array}$ \\
\hline 2. & $\begin{array}{l}\text { Istana Madu } \\
\text { Aneka Nektar }\end{array}$ & 21 & Produk lebah lengkap \\
\hline 3. & Madu Murni & 15 & $\begin{array}{l}\text { Madu ny murni kualitas baik, harga terjang- } \\
\text { kau, belanja madu di sini saja }\end{array}$ \\
\hline 4. & Madu Asoha Malang & 15 & $\begin{array}{l}\text { sangat bermanfaat, berkualitas, asli tan- } \\
\text { pa tipu tipu... rekomended insyaaAllah }\end{array}$ \\
\hline 5. & Madu Asli Kota Batu & 18 & Lokasi strategis,harga murah, kualitas \\
\hline 6. & $\begin{array}{l}\text { Madu Tawon } \\
\text { Asli Malang }\end{array}$ & 23 & $\begin{array}{l}\text { Recomended banget, baru kali ini cocok den- } \\
\text { gan madunya. Sebelumnya dah nyoba di- } \\
\text { mana mana g cocok, lakok ini sekali nyoba } \\
\text { terasa g serik dn anakku doyan. Makasih } \\
\text { Madu Tawon Asli Malang. Tetap jaga kualitas } \\
\text { produknya Gan }\end{array}$ \\
\hline 7. & $\begin{array}{l}\text { Madunesia Madu } \\
\text { Malang Asli Murni }\end{array}$ & 21 & $\begin{array}{l}\text { Madu nya asli dari lebah nektar bunga, bisa } \\
\text { coba macam-macam nya produk lebah }\end{array}$ \\
\hline
\end{tabular}

Sumber: Ulasan Google, 2020

Bataineh (2015), keputusan untuk membeli suatu produk dipengaruhi oleh kepercayaan pelanggan yang tercermin melalui ulasan yang baik yang telah dibaca. Penerapan ulasan didefinisikan sebagai sejauh mana seseorang menerima pesan setelah dia mengevaluasi informasi dalam pesan dengan hati-hati dan menganggapnya bermakna dan bermanfaat (Lee \& Koo, 2012).

Salah satu faktor yang mempengaruhi minat pembeli yaitu besarnya rating dan banyaknya ulasan. Hal itu mempengaruhi terhadap hasil penjualan yang akan mengalami peningkatan setelah dilihat pada waktu konsumen memberikan ulasan yang terekam adalah pada masa pandemi. Hal ini sesuai dengan pendapat Huda (2020), bahwa beberapa produk mengalami kenaikan penjualan sebanyak $25 \%$ pada e-commerse salah satu dari produk tersebut adalah produk yang dapat meningkatkan imunitas tubuh. Bila penjualan mengalami kenaikan maka pasar akan mudah untuk dikuasai.

\section{SIMPULAN}

Strategi pemasaran menggunakan eWOM pada agribisnis madu di wilayah Malang sudah berjalan baik. Semakin banyak rating dan jumlah ulasan maka semakin berdampak baik pada penjualan dan reputasi penjual serta produk yang dijual sehingga dapat memudahkan dalam menjangkau target pasar. Isi ulasan banyak yang memberikan kesan yang positif dibandingkan kesan yang negatif terhadap produk madu di wilayah Malang. Pada masa pandemi produsen dan penjual madu di wilayah Malang mengalami peningkatan penjualan yang baik, karena madu merupakan produk yang dapat membantu meningkatkan imunitas.

\section{DAFTAR PUSTAKA}

Agustina, L., Fayardi, A. O., \& Irwansyah, I. (2018). Online Review: Indikator Penilaian Kredibilitas Online dalam Platform E-commerce. Jurnal ILMU KOMUNIKASI, 15(2), 141. https:// doi.org/10.24002/jik.v15i2.1320. 
Bagaskara. (2017). Menggunakan google review untuk membuat bisnis anda menonjol di internet. https://www. kompasiana.com/igodigital

Bataineh, A. Q. (2015). The Impact of Perceived e-WOM on Purchase Intention: The Mediating Role of Corporate Image. International Journal of Marketing Studies, 7(1), 126-137. https://doi.org/10.5539/ ijms.v7n1p126

Chang, H. H., \& Wu, L. H. (2014). An examination of negative e-WOM adoption: Brand commitment as a moderator. Decision Support Systems, 59(1), 206-218. https://doi. org/10.1016/j.dss.2013.11.008

Diaz, M. R., \& R, T. F. E. R. (2018). Determining the reliability and validity of online reputation databases for lodging: Booking. com, TripAdvisor, and HolidayCheck. Journal of Vacation Marketing, 24(3), 261-274. https://journals.sagepub.com/doi/ abs/10.1177/1356766717706103

Duarte, P., Costa e Silva, S., \& Ferreira, M. B. (2018). How convenient is it? Delivering online shopping convenience to enhance customer satisfaction and encourage e-WOM. Journal of Retailing and Consumer Services, 44(June), 161-169. https://doi.org/10.1016/j. jretconser.2018.06.007

Eteraf-Oskouei, T., \& Najafi, M. (2013). Traditional and modern uses of natural honey in human diseases: A review. Iranian Journal of Basic Medical Sciences, 16(6), 731742 . https://doi.org/10.22038/ ijbms.2013.988
Gupta, P., \& Harris, J. (2010). How e-WOM recommendations influence product consideration and quality of choice: A motivation to process information perspective. Journal of Business Research, 63(9-10), 10411049. https://doi.org/10.1016/j. jbusres.2009.01.015

Harahap, D. A. (2018). Perilaku Belanja Online Di Indonesia: Studi Kasus. JRMSI - Jurnal Riset Manajemen Sains Indonesia, 9(2), 193213. https://doi.org/10.21009/ jrmsi.009.2.02

Huda, L. (2020). Kenaikan Penjualan E-commerce 25 Persen selama Pandemi. https://bisnis.tempo. $\mathrm{co} / \mathrm{read} / 1404513 /$ idea-kenaikanpenjualan-e-commerce-25-persenselama-pandemi

Jayuli, M., Junus, M., \& Nursita, W. (2018). Pengaruh Ketingian Terhadap Diameter Polen Lebah Madu (Apis Cerana) Di Kabupaten Malang. TERNAK TROPIKA Journal of Tropical Animal Production, 19(1), 9-21. https://doi.org/10.21776/ ub.jtapro.2018.019.01.2

Kamilah, M. F. (2019). Analisis Edukasi Penggunaan Madu Sebagai Obat Komplementer pada Pharyngitis. https://doi.org/10.31227/osf.io/7mj92

Kumalasari, R., Gutama, W., \& Pratiwi, D. (2018). Analisis Pengaruh Electronic Word of Mouth (eWOM) Terhadap Keputusan Berkunjung ke Agrowisata Café Sawah Pujon Kidul. Habitat, 29(2), 6575. https://doi.org/10.21776/ ub.habitat.2018.029.2.8 
Lee, K. T., \& Koo, D. M. (2012). Effects of attribute and valence of e-WOM on message adoption: Moderating roles of subjective knowledge and regulatory focus. Computers in Human Behavior, 28(5), 19741984 . https://doi.org/10.1016/j. chb.2012.05.018

López, M., \& Sicilia, M. (2014). Determinants of E-WOM influence: The role of consumers' internet experience. Journal of Theoretical and Applied Electronic Commerce Research, 9(1), 28-43. https://doi.org/10.4067/ S0718-18762014000100004

Mungkasa, O. (2020). Bekerja dari Rumah (Working From Home/ WFH): Menuju Tatanan Baru Era Pandemi COVID 19. Jurnal Perencanaan Pembangunan: The Indonesian Journal of Development Planning, 4(2), 126-150. https://doi. org/10.36574/jpp.v4i2.119

Nanda, M. S., Mittal, S. P., \& Gupta, V. (2017). Role of honey as adjuvant therapy in patients with sore throat. National Journal of Physiology, Pharmacy and Pharmacology, 7(4), 412-415. https://doi.org/10.5455/ njppp.2017.7.1233125122016
Purbohastuti, A. wahyuni, \& Hidayah, A. A. (2020). Meningkatkan Minat Beli Produk Shopee Melalui Celebrity Endorser. Jurnal Bisnis Terapan, 4(1), 37-46. https://doi.org/10.24123/ jbt.v4i1.2480

Setiawan, P. Y., Troena, E. A., \& Noermijati Armanu. (2014). The effect of e-WOM on destination image, satisfaction and loyalty. International Journal of Business and Management Invention, 3(1), 22-29.

Tim Kerja Kementerian Dalam Negeri. (2020). Pedoman Umum Menghadapi Pandemi Covid-19 Bagi Pemerintah Daerah: Pencegahan, Pengendalian, Diagnosis dan Manajemen. Journal of Chemical Information and Modeling, 53(9), 1689-1699. https://doi.org/10.1017/ CBO9781107415324.004. 